\title{
COLORED WHEAT: ANTHOCYANIN CONTENT, GRAIN FIRMNESS, DOUGH PROPERTIES, BUN TEXTURE PROFILE
}

\author{
Martin Král' , Jana Pokorná ${ }^{1}$, Bohuslava Tremlová1, Martina Oštádalová ${ }^{1}$, \\ Václav Trojan², Tomáš Vyhnánek², Maria Walczycka ${ }^{3}$
}

\begin{abstract}
'Department of Plant Origin Foodstuffs Hygiene and Technology, Faculty of Veterinary Hygiene and Ecology, University of Veterinary and Pharmaceutical Sciences Brno, Palackého tř.1946/1, 61242 Brno, Czech Republic ${ }_{2}^{2}$ Department of Plant Biology, Faculty of AgriSciences, Mendel University in Brno, Zemědělská 1, 61300 Brno, Czech Republic

${ }^{3}$ Department of Animal Products Processing, Faculty of Food Technology, University of Agriculture in Krakow, Balicka 122, 30-149 Kraków, Poland
\end{abstract}

\begin{abstract}
KRÁL MARTIN, POKORNÁ JANA, TREMLOVÁ BOHUSLAVA, OŠŤÁDALOVÁ MARTINA, TROJANVÁCLAV,VYHNÁNEKTOMÁŠ, WALCZYCKAMARIA.2018. Colored Wheat:Anthocyanin Content, Grain Firmness, Dough Properties, Bun Texture Profile. Acta Universitatis Agriculturae et Silviculturae Mendelianae Brunensis, 67(3): 685-690.

The aim of this study was to determine the total anthocyanin content and firmness of three spring wheat varieties Triticum aestivum L. (Vanek, UC66049 and Konini) and evaluate the relationship between its flour and texture parameters of the dough and bun. Total anthocyanin content in grain varieties varied from 6.70 to $47.63 \mathrm{mg} . \mathrm{kg}^{-1}$. In colored wheat was observed approximately seven times more content compared with the control. The highest firmness was obtained in purple $(27.62 \mathrm{~N})$ and the lowest in blue grain $(22.31 \mathrm{~N})$. The lowest stickiness was found in blue wheat dough and therefore, it would be more suitable for manufacturing. Blue wheat decreased the dough cohesiveness and work of adhesion. The crumb hardness was significantly lowest in blue batch $(\mathrm{P}<0.01)$ in 100 and $90 \%$ concentration and in $80 \%$ mixture was control significantly highest $(\mathrm{P}<0.01)$. The lower addition of colored wheat flour increased bun springiness. In $100 \%$ and $90 \%$ concentrations were highest values of gumminess observed in purple batch and lowest in blue, but in $80 \%$ concentration was control highest and purple batch was lowest and the same tendency was observed in bun chewiness.
\end{abstract}

Keywords: purple wheat, blue wheat, UV-VIS spectrophotometer, texture analyzer, bakery products

\section{INTRODUCTION}

Wheat is a main cereal used to make bread, pasta, and noodles, because among the cereal flours, only wheat flour has the ability to form cohesive doughs upon hydration (Létang et al., 1999; Landillon et al., 2008) and also for its valuable chemical composition. The colour in wheat grain is mainly due to natural pigments such as carotenoids and anthocyanins. These substances accumulate in the aleurone or pericarp of wheat and provide the blue, purple and red colours of the grain (Ficco et al., 2014). Liu et al. (2010) described anthocyanins as the major compounds distinguishing purple and blue wheat with high antioxidant activity and as well as herbal anthocyanins are functioning as antioxidants and, in addition, they have anti-bacterial and anti-carcinogenic effects as well (Liu et al., 2010; Varga et al., 2013).

Flour components and the rheological properties of the dough often affect bread properties (Rózylo and Laskowski 2011). Water and wheat flour mixture results in a viscoelastic material, the dough with characteristic physical properties which strongly influence dough machinability and the quality of the finished product (Armero and Collar 1997). 
Factors that affect the stickiness of foods are the interactions of two forces: adhesive and cohesive (Hoseney and Smewing 1999).

The aim of this study was to determine the total anthocyanin content of three spring wheat varieties Triticum aestivum and rheological properties of grain, dough and bun as a final bakery product.

\section{MATERIAL AND METHODS}

\section{Cereal grains}

Three types of spring variety grain wheats Triticum aestivum L. were used in the present study: Control - anek (Volume weight (VW) - 814 g.l-1, Nitrogen content (NC) - 11.9\%); Blue - UC66049 (VW 729 g.l-1, NC - 16.2\%) and Purple - Konini (VW 755 g.l $^{-1}, \mathrm{NC}-14.7 \%$ ).

\section{Anthocyanin determination}

The extraction of anthocyanins was performed according to Abdel-Aal et al. (2006) with slight modification (Varga et al., 2013). The total anthocyanin content (TAC, mg. $\mathrm{kg}^{-1}$ ) was calculated and expressed as cyanidin-3-glucoside equivalents.

\section{Texture measurements}

Wheat grain firmness, Dough properties and Bun Texture profile measurements were performed with TA-XT Plus Texture Analyzer (Stable Micro System Surrey, UK).

\section{Wheat grain firmness}

Wheat seeds were kept in covered beakers at the laboratory temperature. Hundred seeds randomly selected per group were analyzed for firmness. A three-inch diameter compression plate was installed to the $25 \mathrm{~kg}$ load cell of the analyzer and setting was adjusted at: $1.5 \mathrm{~mm} . \mathrm{s}^{-1}$ pre-test speed; $1.5 \mathrm{~mm} . \mathrm{s}^{-1}$ test speed and $10.0 \mathrm{~mm} . \mathrm{s}^{-1}$ post-test speed. All samples were cut across their original height using an Upper wedge of Fracture wedge probe.

\section{Dough preparation}

Doughs were produced by using three different wheat varieties: control, blue and purple (described in the subchapter - Cereal Grains). Wheats were milled to wholemeal flour using laboratory mill LM 3100 (Perten Instruments AB, Sweden). Ingredients were mixed according to ratio mentioned in table I until total incorporation in a kneading machine Vorwerk (Vorwerk and Co. KG, Germany) for 8.5 minutes. After that, doughs matured at $31{ }^{\circ} \mathrm{C}$ in humid conditions for 15 minutes in climatic chamber BMT mmM Group, Ecocell 55 (Germany). Matured doughs were divided into $40 \mathrm{~g}$ pieces, they were hand-molded and then matured at $31^{\circ} \mathrm{C}$ in a humid conditions for 30 minutes.

\section{Dough properties}

The prepared dough was evaluated using SMS/Chen-Hoseney Dough Stickiness Rig test (Texture Technologies Corp., UK) using accessories such as $25 \mathrm{~mm}$ perspex cylinder probe $(\mathrm{P} / 25 \mathrm{P})$ (Texture Technologies Corp., UK) which has a uniform adherence surface and SMS/Chen-Hoseney Dough Stickiness Cell (A/DSC). In this test, prior to the measurement, dough strands of $1 \mathrm{~mm}$ length are extruded through holes of the dough stickiness cell. Test setting was adjusted at: $0.5 \mathrm{~mm} . \mathrm{s}^{-1}$ pre-test speed; $0.5 \mathrm{~mm} . \mathrm{s}^{-1}$ test speed and $10.0 \mathrm{~mm} . \mathrm{s}^{-1}$ post-test speed (Hoseney and Smewing 1999).

\section{Dough baking}

Matured pieces of doughs were placed in baking pans, sprayed by water and baked at $250^{\circ} \mathrm{C}$ for 15 minutes in the electric oven. Pieces were also sprayed by water in half of baking time and 5 minutes before ending of baking. After baking, buns were placed on plates and cooled in room temperature. Three replicates measurements with 15 pes of sample per group were performed after 24 hours of baking.

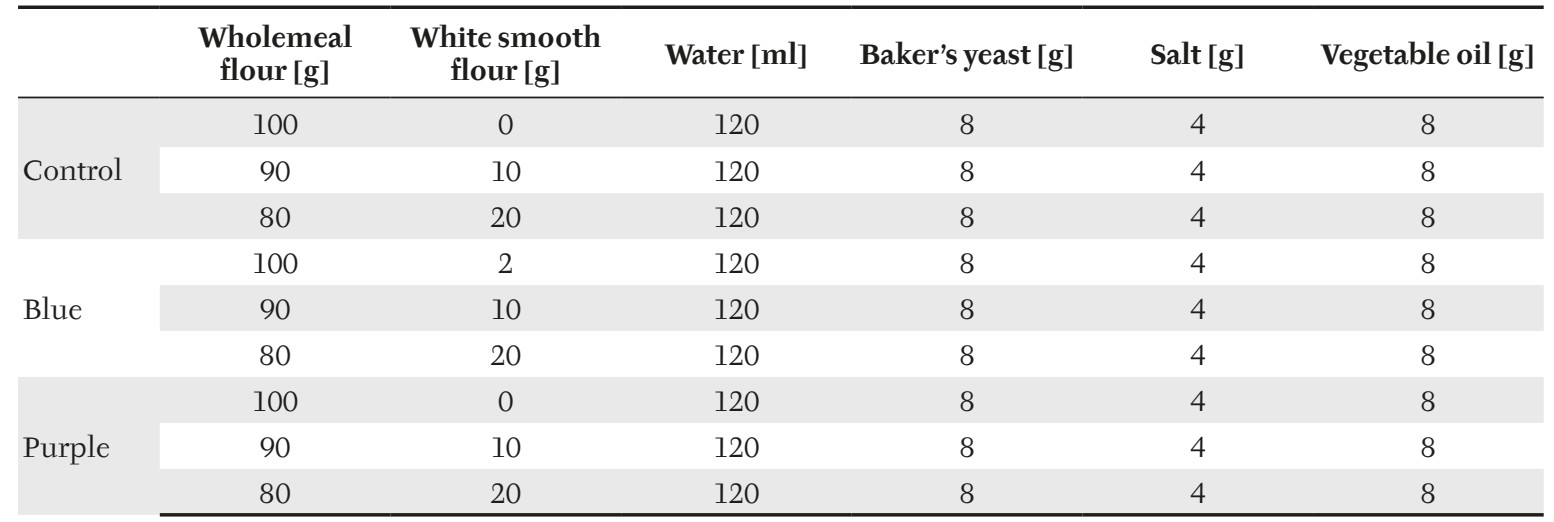

Wholemeal flour [g] = batch [\%] 


\section{Bun texture profile}

Bun was placed centrally on three-inch diameter compression plate. A double compression cycle test was performed with an aluminum cylinder probe of $38 \mathrm{~mm}$ diameter. Hardness, springiness, cohesiveness, gumminess and chewiness were calculated according to (Armero and Collar 1997) and test was adjusted at: $1.0 \mathrm{~mm} . \mathrm{s}^{-1}$ pre-test speed; $2.0 \mathrm{~mm} \cdot \mathrm{s}^{-1}$ test speed and $2.0 \mathrm{~mm} \cdot \mathrm{s}^{-1}$ post-test speed. Values were the mean of 3 replicates with 15 pcs of sample per group.

\section{Statistical analysis}

Data were statistically expressed using analysis of variance ANOVA and Tukey post hoc test was used for finding differences within individual groups at the $P<0.01$ level. Statistical analysis of data was performed using Unistat 6.1, Ltd., 2012, Czech Republic.

\section{RESULTS AND DISCUSSION}

\section{Anthocyanin content and grain firmness}

TAC of varieties varied from 6.70 to $47.63 \mathrm{mg}$. $\mathrm{kg}^{-1}$ according to genotype (Tab. II). Colored wheat had approximately seven times more when compared with the control. According to Žofajová et al. (2012), the anthocyanin content of the blue variety was $193.38 \mathrm{mg} . \mathrm{kg}^{-1}$ and, while those of purple lines were 37.8 (ANK-28A) and $34.5 \mathrm{mg} \cdot \mathrm{kg}^{-1}(62 / 0)$. These values are higher than those found in our experiment (blue 47.63 and purple $41.70 \mathrm{mg} . \mathrm{kg}^{-1}$ ). Our results are comparable with those found Varga et al. (2013). Anthocyanin content is influenced by environmental factors, e.g. soil and weather conditions (Yang and Jie 2007; Bustos et al. 2012). Our results are in agreement with other studies regarding the observation that blue wheat contains higher anthocyanin content than purple wheat.

In general, the farmer makes more profit with harder textured wheat (Turnbull and Rahman 2002; USDA-ERS, 2012). Soft wheat flour is generally used for producing cakes and cookies and on the other side, hard for bread, and durum for pasta. Pauly et al. (2013) described that bread can also be made with soft or durum wheat flour, and cookies and cakes can also be made from hard wheat flour. The highest firmness was obtained in purple grain $(27.62 \mathrm{~N})$ and the lowest in blue grain (22.31 N). Purple grain was significantly different $(\mathrm{P}<0.01)$ from control and blue wheat (Tab. II). Wheat grain softness or hardness is greatly associated with the thickness, and these values can be affected with differences in the moisture content (Elbatawi and Arafa 2008)

\section{Dough properties}

The dough stickiness is affected by many factors as wheat varieties, growing season, protein concentration, water absorption, milling process and extraction rate (Van Velzen et al., 2003; Yildiz et al., 2012). Adhesiveness is a surface property, but in TPA (texture profile analysis) adhesiveness is measured as a compound property of surface adhesiveness, cohesiveness and hardness (viscosity or fluidity); therefore, it should be termed "apparent adhesiveness" (Armero and Collar 1997). According Hoseney and Smewing (1999) is Chen and Hoseney method for measurement of dough stickiness which minimizes the interference from cohesiveness and hardness. Dough properties expressed as stickiness, cohesiveness and work of adhesion measurements are shown in Tab. III.

The highest stickiness was found for purple dough in $100 \%(26.07 \mathrm{~N})$ in $90 \%(22.62 \mathrm{~N})$ and in $80 \%(30.80 \mathrm{~N})$ and the lowest for blue dough $100 \%(15.79 \mathrm{~N}), 90 \%(17.43 \mathrm{~N})$ and $80 \%(24.96$ $\mathrm{N})$. The stickiest dough (purple dough) showing

II: Wheat total anthocyanin content $(n=20)$ and grain firmness

\begin{tabular}{lcc}
\hline & Anthocyanin $\left(\mathbf{m g} \cdot \mathbf{k g}^{-1}\right)$ & Firmness (N) \\
\hline Control & $6.70 \pm 0.2^{\mathrm{ab}}$ & $23.72 \pm 2.9^{\mathrm{a}}$ \\
Blue & $41.70 \pm 1.5^{\mathrm{a}}$ & $27.62 \pm 3.3^{\mathrm{ab}}$ \\
Purple & $47.63 \pm 1.4^{\mathrm{b}}$ & $22.31 \pm 1.9^{\mathrm{b}}$ \\
\hline
\end{tabular}

Results are shown as mean. Means in same column with same letter are significantly different $(\mathrm{P}<0.01)$.

III: Dough properties (dough stickiness, dough cohesiveness, work of adhesion)

\begin{tabular}{|c|c|c|c|c|c|c|c|c|c|}
\hline & \multicolumn{3}{|c|}{$100 \%$} & \multicolumn{3}{|c|}{$90 \%$} & \multicolumn{3}{|c|}{$80 \%$} \\
\hline & Control & Purple & Blue & Control & Purple & Blue & Control & Purple & Blue \\
\hline $\mathrm{D}^{\mathrm{S}}(\mathrm{N})$ & $24.27 \pm 2.1^{\mathrm{a}}$ & $26.07 \pm 2.4^{b}$ & $15.79 \pm 1.4^{\mathrm{ab}}$ & $18.05 \pm 1.3^{a}$ & $22.62 \pm 2.1^{\mathrm{ab}}$ & $17.43 \pm 1.4^{b}$ & $29.37 \pm 3.1^{\mathrm{a}}$ & $30.80 \pm 2.9^{b}$ & $24.96 \pm 2.7^{7 \mathrm{~b}}$ \\
\hline $\mathrm{D}^{\mathrm{C}}(\mathrm{mm})$ & $0.49 \pm 0.0^{a}$ & $0.51 \pm 0.1^{b}$ & $0.34 \pm 0.0^{\mathrm{ab}}$ & $0.38 \pm 0.0^{a}$ & $0.55 \pm 0.1^{\mathrm{ab}}$ & $0.35 \pm 0.0^{b}$ & $0.58 \pm 0.1$ & $0.61 \pm 0.1^{a}$ & $0.50 \pm 0.1^{a}$ \\
\hline $\mathrm{A}^{\mathrm{s}}(\mathrm{N} \mathrm{mm})$ & $0.67 \pm 0.1^{\mathrm{a}}$ & $0.74 \pm 0.2^{b}$ & $0.41 \pm 0.0^{\mathrm{ab}}$ & $0.49 \pm 0.1^{a}$ & $0.69 \pm 0.1^{\mathrm{ab}}$ & $0.46 \pm 0.1^{b}$ & $0.93 \pm 0.2^{a}$ & $1.02 \pm 0.1^{\mathrm{b}}$ & $0.70 \pm 0.1^{\mathrm{ab}}$ \\
\hline
\end{tabular}

Results are shown as mean. $\mathrm{D}^{\mathrm{S}}$ - dough stickiness, $\mathrm{D}^{\mathrm{C}}$ - dough cohesiveness, $\mathrm{A}^{\mathrm{s}}$ - work of adhesion. Means in same row with same letter for concentration are significantly different $(\mathrm{P}<0.01)$. 
the highest force in all concentration, therefore it is not suitable for processing. The importance of sticky dough is even greater, when dough is handled by machine and less by the baker's hand (Hoseney and Smewing 1999).

The same tendency as for stickiness was observed in other dough parameters, when the highest value for cohesiveness was obtained in purple dough (100, $90,80 \%-0.51,0.55,0.61 \mathrm{~N})$ and lowest in blue dough $(100,90,80 \%-0.34,0.35,0.50 \mathrm{~N})$ and the highest adhesion (100, 90, 80\% - 0.74, 0.69, $1.02 \mathrm{~N})$ was also in purple and the lowest in blue dough (100, 90, 80\% - 0.41, 0.46, 0.70 N). Significant difference $(p<0.01)$ was observed in all concentration for all parameters between purple and blue dough and between blue and control, excepted $\mathrm{D}^{\mathrm{C}}$ in $80 \%$ concentration when difference was only between purple and blue dough.

Armero and Collar (1997) reported that wheat dough cohesiveness is a good predictive parameter of fresh-baked product quality. The more-cohesive wheat doughs produce softer breads with higher specific volumes

High values of areas under the curves as recorded for purple (1.02 $\mathrm{N} \mathrm{mm}$ ) and control (0.93 $\mathrm{N} \mathrm{mm}$ ) in $80 \%$ dough concentration, suggest that its concentration has a very sticky dough compared to other concentration and blue dough with relatively low value in any concentration. Decrease in works of adhesion was observed when the dough concentration increased from $80 \%$ to higher value. Reduction of adhesiveness is according Rudolph and Tscheuner (1979) a significant property for the industrialist. The high adhesiveness can cause interruption of the production and contamination of materials.

\section{Bun texture profile}

Bun texture profile results are shown in table IV. Spices (1990), describes bread hardness as an index of quality and its change is frequently accompanied with the loss of resilience during storage. In our experiment the purple batch bun was hardest compared to all test buns in 100 and 90\% concentration, but in $80 \%$ purple batch bun had the lowest value. The blue batch was significantly lowest $(\mathrm{P}<0.01)$ in 100 and $90 \%$ concentration and in $80 \%$ was control significantly highest $(\mathrm{P}<0.01)$.

Bun springiness show that the control and blue batch bun in $80 \%$ concentration showed higher values $(0.90 \mathrm{~mm})$ for springiness and on the other hand in $100 \%$ were values 0.81 to $0.82 \mathrm{~mm}$. A reduction in springiness value indicates the loss of elasticity. Our results shown that lower addition of colored wheat flour, increased springiness and therefore the final products are more elastic.

High springiness values of the bread are related to the freshness and elasticity, and therefore are more preferred. Marco and Rosell (2008) and Matos and Rosell (2012) discovered lower springiness in gluten free rice bread after $12 \mathrm{~h}$ of germination. Therefore control and blue batch bun in $80 \%$ concentration can be more preferable for consumers. Springiness was not significantly affected in 100 and $90 \%$.

Cohesiveness defines the internal resistance of bakery structure. For cohesiveness, control in $100 \%$ had lowest values than the rest of the buns, where values ranged from 44 to 47 . According to Onyango et al. (2010), are low cohesiveness breads are susceptible to fracture and crumble.

Gumminess is calculated by multiplying hardness by cohesiveness and chewiness is calculated by multiplying hardness by cohesiveness and springiness. Our results show that in 100 and 90\% concentration were highest values of gumminess observed in purple batch buns and lowest in blue, but in $80 \%$ was control highest and purple batch was lowest and the same tendency was observed in bun chewiness. According to Bhol and Bosco (2014), changes in the gumminess may be due by the influence of water absorption capacity and variations in chemical compositions.

IV: Bun texture profile (hardness, springiness, cohesiveness, gumminess, chewiness).

\begin{tabular}{|c|c|c|c|c|c|c|c|c|c|}
\hline & \multicolumn{3}{|c|}{$100 \%$} & \multicolumn{3}{|c|}{$90 \%$} & \multicolumn{3}{|c|}{$80 \%$} \\
\hline & Control & Purple & Blue & Control & Purple & Blue & Control & Purple & Blue \\
\hline $\mathrm{H}(\mathrm{N})$ & $52.30 \pm 4.7^{a}$ & $57.00 \pm 33^{b}$ & $32.75 \pm 2.6^{\mathrm{ab}}$ & $54.20 \pm 3.8^{a}$ & $57.31 \pm 43^{b}$ & $44.15 \pm 2.6^{\mathrm{ab}}$ & $48.71 \pm 1.5^{\mathrm{ab}}$ & $37.66 \pm 3.1^{a}$ & $37.70 \pm 2.4^{b}$ \\
\hline $\mathrm{S}(\mathrm{mm})$ & $0.82 \pm 0.0$ & $0.81 \pm 0.1$ & $0.81 \pm 0.1$ & $0.87 \pm 0.2$ & $0.82 \pm .0 .0$ & $0.89 \pm 0.1$ & $0.90 \pm 0.2^{\mathrm{a}}$ & $0.86 \pm 0.0^{\mathrm{ab}}$ & $0.90 \pm 0.0^{b}$ \\
\hline$C(-)$ & $0.38 \pm 0.0^{a}$ & $0.45 \pm 0.0^{\mathrm{a}}$ & $0.44 \pm 0.1$ & $0.47 \pm 0.1$ & $0.47 \pm 0.1$ & $0.47 \pm 0.1$ & $0.46 \pm 0.0^{a}$ & $0.46 \pm 0.1^{b}$ & $0.47 \pm 0.1^{\mathrm{ab}}$ \\
\hline$G(-)$ & $19.92 \pm 1.2^{2 b}$ & $25.76 \pm 2.5^{b c}$ & $14.41 \pm 1.2^{\mathrm{ac}}$ & $25.45 \pm 1.3^{a}$ & $27.11 \pm 1.6^{b}$ & $20.79 \pm 2.0^{\mathrm{ab}}$ & $22.55 \pm 2.1^{\mathrm{ab}}$ & $17.38 \pm 1.8^{\mathrm{a}}$ & $18.03 \pm 1.6^{\mathrm{b}}$ \\
\hline $\mathrm{Ch}(\mathrm{Nmm})$ & $16.80 \pm 1.5^{\mathrm{ab}}$ & $21.36 \pm 2.2^{\mathrm{bc}}$ & $11.75 \pm 0.2^{\mathrm{ac}}$ & $22.35 \pm 1.8^{\mathrm{a}}$ & $22.47 \pm 1.5^{b}$ & $18.48 \pm 13^{\mathrm{ab}}$ & $20.42 \pm 2.4^{\mathrm{ab}}$ & $14.96 \pm 0.6^{a c}$ & $16.37 \pm 0.7^{\mathrm{bc}}$ \\
\hline
\end{tabular}

Results are shown as mean. $\mathrm{H}$ - hardness, $\mathrm{S}$ - springiness, $\mathrm{C}$ - cohesiveness, $\mathrm{G}$ - gumminess, Ch - chewiness Means in same row with same letter for concentration are significantly different $(P<0.01)$.

\section{CONCLUSION}

Anthocyanin compositions of colored wheat such as purple and blue are major indicator in designating the health benefits of cereal products. Colored wheat contained approximately seven times more anthocyanins than control group. Hardness is one of wheat characteristic with important consequences for the supply chain. This study showed differences in grain firmness, dough and bun 
quality parameters using different type of wheat. The highest firmness was obtained in purple grain and the lowest in blue grain. The lowest stickiness was found for dough from blue wheat and therefore, it would be more suitable for manufacturing. Similarly, using blue wheat decreased the dough cohesiveness and work of adhesion. Bun with blue grain showed the lowest crumb hardness and higher cohesiveness and therefore it is believed to be less susceptible to crumble.

Acknowledgement

We are grateful for proofreading of English Professor Kristin Burkholder, University of New England, USA. This work was supported by IGA No. 215/2017/FVHE project.

\section{REFERENCES}

ABDEL-AAL, E. S. M., YOUNG, J. C. and RABALSKI, I. 2006. Anthocyanin composition in black, blue, pink, purple, and red cereal grains. Journal of Agricultural and Food Chemistry, 54(13): 4696-4704.

ARMERO, E. and COLLAR, C. 1997. Texture properties of formulated wheat doughs: relationships with dough and bread technological quality. Zeitschrift für Lebensmitteluntersuchung und Forschung A, 204: 136-145.

BHOL, S. and BOSCO, S. J. 2014. Influence of malted finger millet and red kidney bean flour on quality characteristics of developed bread. Lebensmittel-Wissenschaft und Technologie, 55: 294-300.

BUSTOS, D. V., RIEGELG, R. and CALDERINI, D. F. 2012. Anhocyanin content of grains in purple wheat is affected by grain position, assimilate availability and agronomic management. Journal of Cereal Science, 55(3): 257-264.

ELBATAWI, I. E. and ARAFA, G. K. 2008. Factors affecting breaking force distribution of wheat kernel before milling. Misr Journal of Agricultural Engineering, 25: 1004-1025.

FICCO, D. B. M., MASTRANGELO, A. M., TRONO, D., BORRELLI, G. M., VITA, P., FARES, C., BELEGGIA, R., PLATANI, C. and PAPA, R. 2014. The colours of durum wheat: a review. Crop and Pasture Science Journal, 65(1): 1-15.

HOSENEY, R. C. and SMEWIG, J. 1999. Instrumental measurement of stickiness of dough and other foods. Journal of Texture Studies, 30: 123-136.

LANDILLON, V., CASSAN, D., MOREL, M-H. and CUQ, B. 2008. Flowability, cohesive, and granulation properties of wheat powders. Journal of Food Engineering, 86: 178-93.

LÉTANG, C., PIAU, M. and VERDIER, C. 1999. Characterization of wheat flour-water doughs. Part I: Rheometry and microstructure. Journal of Food Engineering, 41: 121-32.

LIU, Q., YANG, Q. and TRUST, B. 2010. Comparison of Antioxidant Activities of Different Colored Wheat Grains and Analysis of Phenolic Compounds. Journal of Agricultural and Food Chemistry, 58: 9235-9241.

MARCO, C. and ROSELL, C. 2008. Breadmaking performance of protein enriched, gluten-free breads. European Food Research and Technology, 227(4): 1205-1213.

MATOS, M. and ROSELL, C. 2012. Relationship between instrumental parameters and sensory characteristics in gluten-free breads. European Food Research and Technology, 235(1): 107-117.

ONYANGO, C., MUTUNGI, C., UNBEHEND, G. and LINDHAUER, M.G. 2010. Rheological and baking characteristics of batter and bread prepared from pregelatinised cassava starch and sorghum and modified using microbial transglutaminase. Journal of Food Engineering, 97(4): 465-470.

PAULY, A., PAREYT, B., FIERENS, E. and DELCOUR, J. A. 2013. Wheat (Triticum aestivum L. and T. turgidum L. ssp.durum) kernel hardness: II. Implication for and role of puroindolines in end-product quality and role of puroindolines therein. Comprehensive Reviews in Food Science and Food Safety, 12: 427-438.

RÓZYLO, R. and LASKOWSKI, J. 2011. Predicting Bread Quality (Bread Loaf Volume and Crumb Texture). Polish Journal of Food and Nutrition Sciences, 61(1): 61-67.

RUDOLPH, H. and TSCHEUNER, H. D. 1979. Adhesiveness in wheat dough. Backer Konditor, 27: 229.

SPICES, R. 1990. Application of rheology in the bread industry, In: FARIDI, H. and FAUBION, J. M. (Eds.). Dough Rheology and Baked Product Texture. Boston, MA: Springer US, pp. 343-361.

TURNBULL, K. M. and RAHMAN, S. 2002. Endosperm texture in wheat. Journal of Cereal Science, 36(3):327-337.

UNITED STATES DEPARTMENT OF AGRICULTURE, ECONOMIC RESEARCH SERVICE. 2012. Wheat data. United States Department of Agriculture. [Online] Available at: http://www.ers.usda.gov [Accessed: 2017, May 25]

VARGA, M., BÁHNIDY, L., CSEUZ, L. and MATUZ, J. 2013. The Anthocyanin Content of Blue and Purple Coloured Wheat Cultivars and their Hybrid Generations. Cereal Research Communications, 41(2): 284-292.

VAN VELZEN, E. J. J., VAN DUYNHOVEN, J. P. M., PUDNEY, P., WEEGELS, P. L. and VAN DER MAAS, J. H. 2003. Factors associated with dough stickiness as sensed by attenuated total reflectance infrared spectroscopy. Cereal Chemistry, 80:378-382.

YANG, W. X. and JIE, X. L. 2007. Sunlight effect on pigment content of purple wheat. Journal of Triticeae Crops, 2: 1101-1105. 
YILDIZ, O., MERAL, R. and DOGAN, I.S. 2012. Determination of stickiness values of different flour combinations. International Journal of Food Engineering, 8(3): 1556-3758.

ŽOFAJOVÁ, A., PŠENÁKOVÁ, I., HAVRLENTOVÁ, M. and PILIAR, M. 2012. Accumulation of total anthocyanins in wheat grain. Journal of Agricultural Science, 58: 50-56.

Contact information

Martin Král: martinxkral@gmail.com

Jana Pokorná: jana.pokorna3@seznam.cz

Bohuslava Tremlová: tremlovab@vfu.cz

Martina Oštádalová: ostadalovam@vfu.cz

Václav Trojan: vaclav.trojan@mendelu.cz

Tomáš Vyhnánek: vyhnanek@mendelu.cz

Maria Walczycka: maria.walczycka@urk.edu.pl 